\title{
Fatty acid composition and organoleptic characteristics of Tilia caucasica Rupr. fruit oil
}

\author{
Samira E. Afandiyeva ${ }^{1}$ \\ Eldar N. Novruzov \\ Institute of Botany, Azerbaijan National Academy of Sciences, \\ Badamdar 40, Baku, AZ1004, Azerbaijan
}

Abstract: The article reports the results of physicochemical, organoleptic characteristics and the fatty acid composition of the oil obtained from the fruits of Tilia caucasica. Data on the qualitative composition and quantitative content of fatty acids for oil from $T$. caucasica fruits growing in Azerbaijan, as well as physico-chemical and organoleptic indicators for oil of this species were established for the first time. It was determined that oil yield of the fruits of $T$. caucasica was $12.89 \%$. The color of $T$. caucasica fruits oil was light yellow, with a pleasant taste and had the following characteristics: content of free fatty acids $-1.99 \mathrm{mmol} /$ $\mathrm{kg}$, peroxide value -3.02 , iodine value -128.4 , mass fraction of phosphorus-containing substances - $91 \mathrm{mmol} /$ $\mathrm{kg}$. The determination of methyl ester level of the oil fatty acids by gas-liquid chromatography revealed the presence of 13 fatty acids: myristic, palmitic, palmitoleic, heptadecanoic, heptadecadienoic, stearic, malvalic, oleic, elaidic, linoleic, linolenic, gandoic, and sterculic. Linoleic acid (46.06\%) was the major polyunsaturated fatty acid, among monounsaturated acids - oleic (16.92\%), among saturated acids - palmitic $(9.36 \%)$ and among cyclopropenoid fatty acids sterculic acid $(13.35 \%)$ presented the highest levels. The evaluation of the physicochemical and organoleptic characteristics, the content of biologically valuable fatty acids in T. caucasica fruit oil allow to recommend it for use in food, medicine and cosmetic purposes.

\section{Key Words: fruit, oil, chromatography}

\section{INTRODUCTION}

The genus Tilia L. (Malvaceae Juss.) includes about 22 species and 12 subspecies [Alverson et al., 1999; Bayer et al., 1999; Pigott, 2002]. Four species and two natural hybrids grow in Europe and South Asia, four in North America, and the others in East Asia [Liesebach, Sinko, 2008; Mccarthy, 2012]. There are three species of

Accepted for publication: 15 April 2020

1E-mail: samire.afandiyeva@gmail.com linden wildly growing in Azerbaijan: T. caucasica Rupr. $(=$ Tilia begoniifolia Stev. $=$ T. prilipkoana Grossh. and J. Wagner.), T. cordata Mill. (= Tilia parvifolia Ehrh. Ex Hoffm.) and T. platypyllos Scop. [Askerov, 2006]. The most widespread species in the republic is $T$. caucasica which is most common in mixed forests of the eastern and western parts of the Greater Caucasus (within Azerbaijan), the Quba massive, the northern and central parts of the Lesser Caucasus and also Lenkaran from the lower to upper mountain zones [Flora of Azerbaijan, 1955].

Linden flowers of the species T. platyphyllos Scop., and $T$. cordata Mill are useful as a sedative, diuretic, diaphoretic and expectorant in folk medicine. The flowers are also widely used for the treatment of headaches and stomachaches, fainting, diseases of the liver, intestines, and kidneys [Gulnur, 1995]. In Jordan Pharmacopeia, the plant is used to treat diabetes [Otoom et al., 2006]. In addition, the fruits are known as a hemostatic and astringent [Kusmenoglu, Toker, 1998].

Many scientists have studied the chemical composition of different parts of linden species. It was revealed that flowers contain flavonoids, essential oil, tannins, glycosides, saponins, vitamin C, volatile oils, carbohydrates [Ahmadi, Mirza, 1999: Akyuz et al., 2013; Fitsiou et al., 2007; Kowalski et al., 2017; Lupinskaya et al., 2010; Popov, Zarubina, 2013; Toker et al., 2001a, b; Zarubina, Popov, 2012].

There were polysaccharides, tannins, triterpene saponins, 35 bioelements, organic acids (malic, oxalic, succinic), vitamin $\mathrm{C}$, flavonoids, and phenolcarboxylic acids in linden bark [Orlovskaya et al., 2013].

Vitamin C, carotenes, amino acids, tannins, flavonoids were found also in linden leaves [Akyuz et al., 2013; Delnavazi et al., 2015; Zarubina, Popov, 2012]. M.I. Lukanyuk and S.M. Marchishin [2012] studied the fatty acid composition of leaves of five Tilia species and reported that palmitic acid among saturated fatty acids, linoleic and linolenic acids among unsaturated were the most abundant in the leaves of all species.

Vegetable fatty oils are the main source providing our body with such essential fatty acids as linoleic, linoleic and arachidic. They are also widely used in the manufacture of medicines [Grigoryeva, Lisishchin, 2002]. One of the important sources of essential fatty 
acids may be products of plant origin, in particular, oils extracted from seeds of wild and cultivated plants. Therefore, identifying new natural sources of essential fatty acids is a priority area for modern science [Zeynalova, Novruzov, 2019].

Despite there are some data contains the composition of fatty acid of oil of various linden species in literature [Bogdanov et al., 2012; Dowd, Ermakov, Panasenko, 2003; Farve, 2013; Karomatov, Abdukhuhidov, 2017; Kusmenoglu, Toker, 1998; Lukanyuk, Marshichin, 2012], but there are no data about species in Azerbaijan. Among three species of the genus Tilia growing in Azerbaijan, T. caucasica has a large stock and widespread distribution.

Taking into account we set out to study the oil content physicochemical parameters, and the composition of fatty acids, of fruit oil T. caucasica, in order to reveal the beneficial properties of this oil.

\section{MATERIAL AND METHODS}

Plant material. The plant material (fruits of $T$. caucasica) was collected in September in 2018 in the phase of full ripeness of fruits in the Quba region of Azerbaijan (482 $23^{\prime} 24^{\prime \prime} \mathrm{E}$; $\left.41^{\circ} 18^{\prime} 40.95^{\prime} \mathrm{N}\right)$.

Extraction. The fruits were dried at $105^{\circ} \mathrm{C}$ for 2 hours on a FAM-100 and then were extracted with n-hexane on a Soxhlet apparatus. The solvent was distilled off in a Rotary Evaporator (ROVA-N2L) and a yield 12.89\% of light yellow oil was obtained.

Oil preparation for analysis was carried out according to GOST 31663-2012. In a test tube with a capacity of $20 \mathrm{ml}, 1 \mathrm{~g}$ oil was weighed out and dissolved in 10 $\mathrm{ml}$ of heptane. Then $0.5 \mathrm{ml}$ of a methanolic solution of potassium hydroxide was added to the resulting solution and vigorously shaken for $2 \mathrm{~min}$. After settling, the top layer was selected for chromatographic analysis. Identification. Fatty acids were converted into their methyl esters according to GOST 31663-2012. HP 6890 gas-liquid chromatograph with flame ionization detector (FID) was used for identification of fatty acids methyl esters (FAMEs). The separation was achieved with capillary column "Agilent 112-88A7" (0.25 mm i.d. $\times 100 \mathrm{~m} \times 0.20 \mu \mathrm{m}$ film thickness). The temperature program was initiated at $140^{\circ} \mathrm{C}$, held for $5 \mathrm{~min}$ and then increased to $240^{\circ} \mathrm{C}$ at $4^{\circ} \mathrm{C}$ per min. Carrier gas was $\mathrm{H}_{2}$, sample injection with flow division. The analysis duration was 45 minutes. Individual FAMEs were identified by comparing to the retention times of standards (Supelco 37 FAME Mix No. 47885-U standard (Sigma Aldrich)). Results are expressed as percentage of total FA [\%FA].

Physicochemical and organoleptic indicators were calculated according to standard following methods: GOST R 50457-92; GOST R 51487-99; GOST 1884873; GOST 5475-69; GOST 5478-2014; GOST R 526762006; GOST 5472-50 [GOST R 50457-92; GOST R 51487-99; GOST 18848-73; GOST 5475-69; GOST 5478-2014; GOST R 52676-2006; GOST 5472-50].

\section{RESULTS AND DISCUSSION}

Physico-chemical and organoleptic properties. In the literature there are no data on the physicochemical and organoleptic indicators of oil from the fruits of $T$. caucasica. These data are very valuable and important for the use of new vegetable oils for food, medicinal and cosmetic purposes, as well as standardization. The results of physico-chemical and organoleptic studies of the oil extracted from the fruits of Tilia caucasica are presented in table.

The oil was light yellow in color, with a pleasant taste and saponification number of $192.8 \mathrm{mg} / \mathrm{kg}$. This indicator is close to sunflower oil [Shah et al., 1984], and to olive oil [Ermakov, Panasenko, 2003], therefore, T. caucasica fatty oil can be recommended for food use.

Table. Physicochemical constants and organoleptic properties of fruit oil of Tilia caucasica Rupr.

\begin{tabular}{ll}
\hline \multicolumn{1}{c}{ Experiment } & \multicolumn{1}{c}{ Result } \\
\hline $\begin{array}{l}\text { Organoleptic parameters } \\
\text { appearance }\end{array}$ & clear liquid \\
colour & light yellow \\
smell & without smell \\
taste & a pleasant taste of seeds \\
\hline Free fatty acids, $\%$ & 1.99 \\
Peroxide value, $\mathrm{mmol} \mathrm{O}_{2} / \mathrm{kg}$ & 3.02 \\
Iodine value, IV & 128.4 \\
Saponification value, $\mathrm{KOH}$ & 192.8 \\
Mass fraction of phosphorus-containing substances, $\mathrm{mg} / \mathrm{kg}$ & 91 \\
\hline
\end{tabular}


The amount of free fatty acids for $T$. caucasica is $1.99 \mathrm{mmol} / \mathrm{kg}$, the peroxide value is 3.02 , the iodine value is 128.4 , and the mass fraction of phosphoruscontaining substances is $91 \mathrm{mmol} / \mathrm{kg}$.

Comparison of the data obtained by us on the physicochemical parameters of $T$. caucasica oils with those of oils from T. platyphyllos seeds show that they differ greatly. Oils from T. caucasica fruits have iodine number 128.4, and T. platyphyllos 59.5, saponification number 192.8 and 240, respectively [Ermakov, Panasenko, 2003].

Fatty acid analysis by gas-chromatography. Gas-liquid chromatography analysis of fatty acid is a very effective method, since separation occurs at a lower temperature and a shorter analysis time. A representative spectrum of gas-liquid chromatography of fatty acids of oil from linden fruits is presented in figure 1. As can be seen from the spectrum, complete separation occurs within 30 minutes.
2. From figure 2, it is evident that linoleic $(46.06 \%)$, oleic $(16.92 \%)$, sterculic $(13.35 \%)$, palmitic $(9.36 \%)$ and malvalic $(8.09 \%)$ acid are the most abundant fatty acid, but heptadecanoic $(0.11 \%)$, gandoic $(0.12 \%)$ and palmitoleic $(0.15 \%)$ acids are the less represented fatty acid. The proportion of the other identified fatty acids is totally $5.23 \%$. The percantage of unidentified fatty acids are $1.13 \%$.

A study of the composition of fatty acids of three linden species ( $T$. argentina, T. platyphyllos, T. rubra) growing in Turkey showed that $T$. platyphyllos and T. rubra contain 10 and $T$. argentina 9 fatty acids [Küsmenoğlu, Toker, 1998]. In the oil of all studied species palmitic, amoung saturated fatty acids, linoleic, oleic acids, amoung unsaturated were dominant. Species differ in the total amount of individual fatty acids. The main fatty acid in T. rubra oil was linoleic, however, in T. platyphyllos - palmitic, in T. argentina was oleic acid.

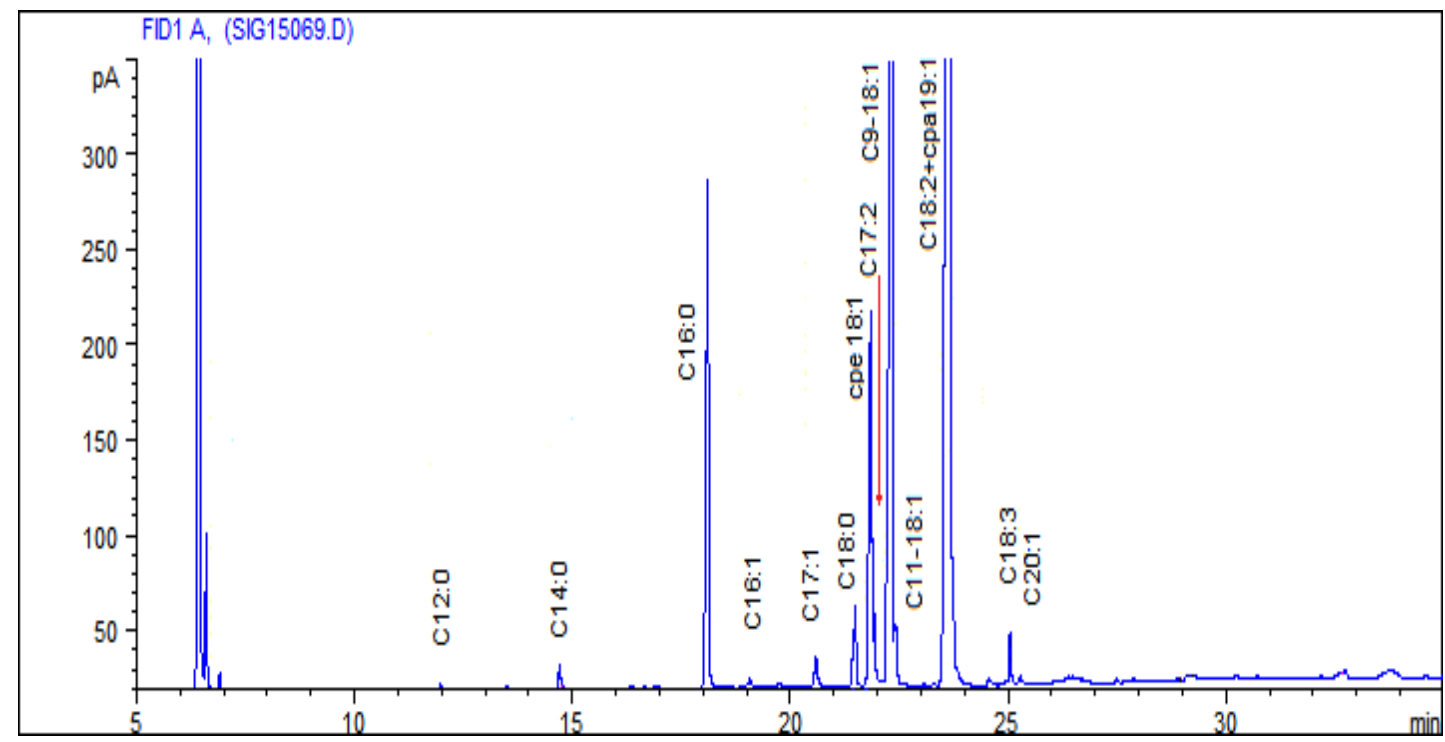

Figure 1. The chromatogram of the fatty acid composition of the oil from the fruits of Tilia caucasica Rupr.

The chromatogram shows that 13 fatty acids were identified in the composition of fatty acids of Tilia caucasica oil: myristic, palmitic, palmitoleic, heptadecanoic, heptadecadienoic, stearic, malvalic, oleic, elaidic, linoleic, linolenic, gandoic, and sterculic.

It can be seen from the chromatogram that the amount of individual fatty acids respect to the total amount is not the same and varies from 0.11 to $46.06 \%$. The identified fatty acids and the percentange of individual identified acids respect to the total amount are presented in figure
M.K. Dowd and M.C. Farve during the study of the fatty acid composition of oils obtained from seeds of 7 linden species, found that in all samples of Tilia spp. seed oils, linoleic acid was the main component of fatty acids; oleic and palmitic acids were present in a smaller amount. This ratio of major and minor fatty acids is characteristic of oils from the seeds of the family Malvaceae. Fatty acids such as myristic, stearic, arachidic, behenic, lignoceric, palmitoleic and cisvaccenic have been established in the oil of seeds of 


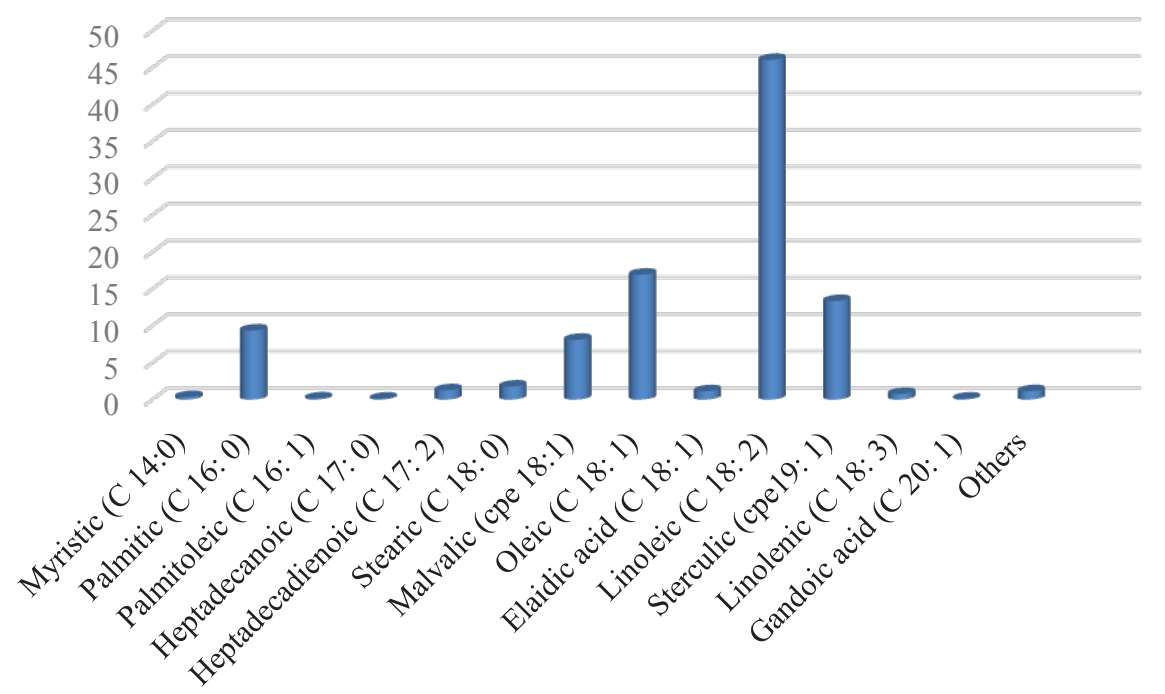

Figure 2. Fatty acid composition of Tilia caucasica Rupr. fruit oil.

various linden species. Heptadecanoic, 9-heptadecenoic, 9,10-epoxystearic, and vernolic acids were in small amount. In the seed oil of $T$. caucasica they identified 15 fatty acids. As dominant fatty acids they reported linoleic-52.4\%, oleic-21.1\%, palmitic-9.76\%, and malvalic-6.14\% [Dowd, Farve, 2013]. The percantage of these acids in our study are $46.6 \%, 16.92 \%, 9.36 \%$, and $8.09 \%$, respectively. As shown they do not differ so much from our results. But among all fatty acids amount of sterculic acid is more significant different. We determined share of this compound $13.35 \%$, however, they presented only $4.30 \%$.

Malvalic and sterculic acids are cyclopropenoid fatty acids. Cyclopropenoid fatty acids were discovered in oil seeds of T. platyphyllos by Raju and Resier [1966] for the first time. The total amount of these acids in the oil was 3.2\%, while M.K. Dowd and M.C. Farve [2013] reported an higher amounts $(9.3 \%)$. A comparative analysis of the literature and our data on the content of cyclopropenoid fatty acids (malvalic $-8.09 \%$ and steric $-13.35 \%$ ) shows that the fruit oil of $T$. caucasica growing in the territory of Azerbaijan contains a rather high amount of these acids respect to previous published data. We believe that perhaps these differences are related to the quality of the seed sample (collection time, fruit maturity, soil and climatic conditions), as well as the technique of obtaining derivatives of thiomethyl used to stabilize the acids. Some authors believe that this is due to the decomposition of compounds in the form of methyl esters during chromatography. Perhaps this occurs during the esterification of acids since cyclopropenoid acids are not stable in acid composition
[Dowd, Farve, 2013].

The analysis of literature data shows that the content of fatty oil from the fruits of various linden species depends on the species and the place of plant growth. So, the fruits of large-leaved linden growing in Russia contain 10-15\% [Bogdanov et al., 2012; Ermakov, Panasenko, 2003] of fatty oil, and in Turkey $8.12 \%$. The yield of oil from the fruits of T. argentina and T. rubra was $5.6 \%$ and $6.16 \%$, respectively [Küsmenoğlu, Toker, 1998]. The results of our studies showed that the fruits of $T$. caucasica differ from other species in their high yield $(12.89 \%)$ of fatty oil.

Linoleic and linolenic acids are essential nutrients for the body and are not naturally produced in it. Therefore, they must be acquired by the body through food [Grigoryeva, Lisishchin, 2002].

Caucasian linden oil is a very valuable product containing a significant amount of essential fatty acid (C18: 2), which is necessary for human health. Our data allow us to consider linden oil as a semi-drying fatty oil with a high content of essential linoleic acid $(46.06 \%)$. It should be noted that linoleic acid, which belongs to the fatty acids of the $\omega-6$ family (omega-6), is a structural element of cell membranes, regulates cholesterol metabolism, participates in the formation of tissue hormones - prostaglandins, and is a biochemical precursor of linolenic and arachidonic acids. Under the influence of microelements, enzymes and vitamins in the body, it turns into gamma-linolenic, from which prostaglandin $\mathrm{E}_{1}$ is synthesized, which, in turn, increases immunity, reduces the risk of cardiovascular diseases, reduces inflammation, regulates the brain and 
nervous system, normalizes insulin level, accelerates metabolism [Vles, Gottenbos, 1989].

The high content of linolenic acids in fruit oil from T. caucasica makes it suitable for the preparation of cosmetic and dermatological compositions as an antioxidant. The results reported in this work suggests that Caucasian linden oil is a valuable food, medical and cosmetic product and can be used for these purposes.

The results of the investigation of physicochemical and organoleptic characteristics and fatty acid composition of Caucasian linden seed oil allow to consider the seed oil of this plant as a good source of dietary fatty acid, especially linoleic acid and recommend it for use in food, medicine and cosmetic purposes.

\section{REFERENCES}

Askerov A.M. (2006) Higher plants of Azerbaijan. II volume. Baku. 283 p. [Osgərov A.M. (2006) Azərbaycanın ali bikiləri. II cild. Bakı. 283 s.]

Ahmadi L., Mirza M. (1999) Volatile constituents of Tilia platyphyllos Scop. flowers. J. Essent. Oil Res. 11: 765-766.

Akyuz E., Şahin H., Islamoglu F., Kolayli S., Sandra P. (2014) Evaluation of phenolic compounds in Tilia rubra subsp. caucasica by HPLC-UV and HPLCUV-MS/MS. Int J Food Prop., 17(2): 331-343.

Alverson W.S., Whitlock B.A., Nyffeler R., Bayer C., Baum D.A. (1999) Phylogenetic analysis of the core Malvales based on sequences of ndhFAm. J. Bot., 86: 1474-1486.

Bayer C., Fay M.F., De Bruijn A.Y., Savolainen V., Morton C.M., Kubitzki K., Alverson W.S., Chase M.W. (1999) Support for an expanded family concept of Malvaceae within a recircum scribed order Malvales: a combined analysis of plastid atpB and rbcL DNA sequences. Bot. J. Linn. Soc., 129: 267-303.

Bogdanov A.N., Lukashova L.A., Ushakova L.S., Zatsepina E.E., Galivka S.S. (2012) Obtaining fatty oil from heart-shaped linden seeds, its analysis and application prospects - Development, research and marketing of the new electronic scientific journal "Biology and Integrative Medicine". Collection of scientific papers. Pyatigorsk., 139(67): 151-153. [Богданов А.Н., Лукашова Л.А., Ушакова Л.С., Зацепина Е.Е., Галивка С.С. (2012) Получение жирного масла из семян липы сердцевидной, его анализ и перспективы применения - Разработка, исследование и маркетинг новой Электронный научный журнал "Биология и интегративная медицина”. Сборник научных трудов. Пятигорск Выnyck, 139(67): 151-153]

Delnavazi M.R., Shahabi M., Yassa N. (2015)Flavonoids from the leaves of Iranian Linden; Tilia rubra subsp. caucasica. Research Journal of Pharmacognosy (RJP), 2(3): 17-22.

Dowd M.K., Farve M.C. (2013) Fatty acid composition of Tilia spp. seed oils. Grasas y aceites, 64(3): 243249.

Ermakov O.A., Panasenko A.I. (2003) Studying the properties of linden seed oil - Bulletin of the Tambov University. Series: Natural and Technical Sciences, 8(1): 127. [Ермаков О.А., Панасенко А.И. (2003) Изучение свойств масла семян липы - Вестник Тамбовского университета. Серия: естественные и технические науки., 8(1): 127]

Fitsiou I., Tzakou O., Hancianu M., Poiata A. (2007) Volatile constituents and antimicrobial activity of Tiliato mentosa Moench and Tilia cordata Miller oils. J. Essent. Oil Res., 19(2): 183-185.

Flora of Azerbaijan. (1955) Genus Tilia L. 6: 208-213. [Флора Азербайджана (1955) Род Tilia L. 6: 208213]

GOST 5472-50. Vegetable oils. Definition of smell, color and transparency. [ГОСТ 5472-50. Масла растительные. Определение запаха, цвета и прозрачности]: 9-12.

GOST 5475-69. Vegetable oils. Methods for determination of iodine value. [ГОСТ 5475-69. Масла растительные. Методы определения йодного числа]: 19-23.

GOST 18848-73. Vegetable oils. Quality indices. Terms and definitions. [ГОСТ 18848-73. Масла растительные. Показатели качества термины и определения]: 11-15.

GOST R 50457-92. Animal and vegetable fats and oils. Determination of acid number and acidity. [ГОСТ Р 50457-92. Жиры и масла животные и растительные. Определение кислотного числа и кислотности]: 1-6.

GOST R 51487-99. Vegetable oils and animal fats. Method for determining peroxide value. [ГОСТ $\mathrm{P}$ 51487-99. Масла растительные и жиры животные. Метод определения перекисного числа]: 1-5.

GOST R 52676-2006. Vegetable oils. Methods for determination of phosphorated substances. [ГОСТ P 52676-2006. Масла растительные. Методы определения фосфорсодержащих веществ] : 1-11. GOST 5478-2014. Vegetable oils and natural fatty 
acids. Method for determination of saponification value [ГОСТ 5478-2014. Масла растительные и натуральные жирные кислоты. Метод определения числа омыления]: 1-4.

Grigoryeva V.N., Lisishchin A.N. (2002) Factors determining the biological usefulness of fat products. Fat-and-oil industry., 4: 14-17. [Григорьева В.Н., Лисицын А.Н. (2002) Факторы, определяющие биологическую полноценность жировых продуктов - Масложировая промышленность., 4: 14-17]

Gulnur T. (1995) Biological activity and use of Linden flowers and peels. FABAD J. Pharm. Sci., 20: 75.

Karomatov I.D., Abduvohidov A.T. (2017) Heartshaped linden - Electronic scientific journal "Biology and Integrative Medicine”., 8: 134-141. Кароматов И.Д., Абдувохидов А.Т. (2017) Липа сердцевидная - Электронный научный журнал «Биология и интегративная медиџина», 8: 134141]

Kowalski R., Baj T., Klaudia K., Kowalski G., Sujka M. (2017) Essential oil composition of Tilia cordata flowers. J. Essent. Oil Bear. Plants, 20(4): 11371142.

Küsmenoğlu S., Toker G. (1998) Fatty acid composition of Tilia fruit oils. Acta. Pharm. Turc., 40: 121-123.

Liesebach H., Sinko Z. (2008) A contribution to the systematics of the genus Tilia with respect to some hybrids by RAPD analysis. Dendrobiology, 59: 1322.

Lukanyuk M.I., Marshichin S.M. (2012) The fatty acid composition of the leaves of some species of linden family. Ukrainian Biopharmaceutical Journal, 1-2: 62-66. [Луканюк М.И., Маршичин С.М. (2012) Жирно-кислотный состав листьев некоторых видов растений семейства липовые. Украінский біофармачевтичний журнал, 1-2: 62-66]

Lupinskaya S.M., Orekhova S.V., Vasilieva O.G. (2010) The study of biologically active substances of linden, nettle and oregano and whey extracts based on them. Chemistry of plant raw materials, 3: 143-145. [Лупинская С.М., Орехова С.В., Васильева О.Г. (2010) Изучение биологически активных веществ липы, крапивы и душицы и сывороточных экстрактов на их основе. Химия растительного сырья, 3: 143-145]

Mccarthy D. (2012) Systematics and phylogeography of the Genus Tilia in North America. Chicago Illinois. $172 \mathrm{p}$.

Orlovskaya T.V., Gulbyakova H.N., Guzhva N.N.,
OgurtsovYu.A. (2013) The study of bark of heart linden in order to create new medicines. Modern problems of science and education, 2: 427. [Орловская Т.В., Гюльбякова Х.Н., Гужва Н.Н., Огурцов Ю.А. (2013) Изучение коры липы сердцелистной с целью создания новых лекарственных средств. Современные проблемь науки и образования, 2: 427]

Otoom S.A., Al-Safi S.A., Kerem Z.K., Alkofahi A. (2006) The use of 141 medicinal herbs by diabetic Jordanian patients. J. Herb. Pharmacother, 6(2): 31-41.

Pigott C.D. (2002) A review of chromosome numbers in the genus Tilia (Tiliaceae). Edinb. J. Bot., 59: 239246.

Popov D.M., Zarubina N.V. (2013) Comparative qualitative and quantitative determination of carbohydrates in the flowers and leaves of linden cordate. Development and registration of medicines, 3: 50-53. [Попов Д.М., Зарубина Н.В. (2013) Сравнительное качественное и количественное определение углеводов в цветках и листьях липы сердцевидной. Разработка и регистращия лекарственных средств, 3: 50-53]

Raju P.K., Reiser R. (1966) Gas-liquid chromatographic analysis of cyclopropene fatty acids. Lipids, 1: 1015.

Shah H.U., Hussain T., Khan M.A. (1984) Pakistan J Agri. Res., 2: 133.

Toker G., Aslan M., Yesilada E., Memisoglu M., Ito S. (2001a) Comparative evaluation of the flavonoid content in officinal Tiliae flos and Turkish lime species for quality assessment. J. Pharm. Biomed. Anal., 26(1): 111-121.

Toker G., Baser H.C., Kürkçüoglu M., Özek T. (2001b) The composition of essential oils from Tilia L. species growing. J. Pharm. Biomed. Anal., 26(1): 111-121.

Vles R.O., Gottenbos J.J. (1989) Nutritional characteristics and food uses of vegetable oils. G. Robblen, R.K. Downey and A. Ashri (Eds.). Oil Crops of the World. McGraw Hill, New York. USA. 63-86.

Zarubina N.V., Popov D.M. (2012) Amino acid composition of linden flowers and leaves. Pharmacy, 5: 21-23. [Зарубина Н.В., Попов Д.М. (2012) Аминокислотный состав цветков и листьев липы. Фармащия, 5: 21-23]

Zeynalova A.M., Novruzov E.N. (2019) Fatty acids composition and physico-chemical constants of 
Punica granatum L. seed oil. Ximiya rastitel'nogo syr'ya, 4: 259-262.

\section{Tilia caucasica Rupr. meyvələrindən alınan yağın yağ-turşu torkibi}

\section{Samirə E. Ofəndiyeva \\ Eldar N. Novruzov \\ AMEA Botanika İnstitutu, Badamdar şossesi 40, Bakl, AZ1004, Azarbaycan}

Məqalədə T. caucasica meyvələrindən əldə edilən yağın yă̆ turşu tərkibi, fiziki-kimyəvi və orqanoleptik xüsusiyyətləri göstərilmişdir. Azərbaycanda bitən T. caucasica növünün meyvələrindən alınmış yağın kəmiyyət və keyfiyyət tərkibi haqda məlumatlar və həmin növün yağının fiziki-kimyəvi və orqanoleptik xüsusiyyətləri ilk dəfə müəyyən olunmuşdur. $T$. caucasica meyvələrindən $12.89 \%$ yağ alınmışdır. Yağın fiziki-kimyəvi və orqanoleptik xüsusiyyətlərinin öyrənilməsi göstərdi ki, T. caucasica meyvələrindən alınan yă̆ xoşagələn dadlı, açıq sarı rəngdədir və aşağıdak1 xüsusiyyətlərə malikdir: sərbəst yağ turşular1$1.99 \mathrm{mmol} / \mathrm{kq}$, peroksid ədədi -3.02, yod ədədi-128.4, tərkibində fosforun ümumi miqdar1-91 mmol/ $\mathrm{kq}$. Qaz-maye xromatoqrafiya üsulu ilə yağın tərkibində 13 yağ turşusu müəyyən edilmişdir: miristin, palmitin, palmitolein, marqarin, heptadekanin, stearin, malvalin, olein, elaidin, linolein, linoleik, qandoin və stearin. Polidoymamış yağ turşuları arasında linolenin $(46.06 \%)$, monodoymamış turşular arasında olein (16.92\%), doymuş turşular arasında palmitin (9.36\%), tsiklopropen turşuları arasında stearin (13.35\%) dominantlıq təşkil edir. Qiymətli yă̆ turşularının olması, o cümlədən yağın fiziki-kimyəvi və orqanoleptik xüsusiyyətləri, T. caucasica meyvələrindən əldə edilmiş yağın qida, dərman və kosmetik məqsədlərlə istifadəsini tövsiyə etməyə imkan verir.

Açar sözlor: meyva, yă̆, xromatoqrafiya

\section{Жирно-кислотный состав масла плодов Tilia caucasica Rupr.}

\section{Самира Э. Эфендиева \\ Эльдар Н. Новрузов}

Институт Ботаники НАНА, Бадамдарское шоссе 40, Баку, АZ1004, Азербайджан

В данной статье приводятся результаты по изучению жирно-кислотного состава, физико-химических и органолептических характеристик масла, полученного из плодов T. caucasica. Данные по качественному составу и количественному содержанию жирных кислот для масла из плодов T. caucasica, произрастающего в Азербайджане, а также физико-химические и органолептические показатели для масла данного вида установлены впервые. Было установлено, что выход жирного масла в плодах T. caucasica составляет $12.89 \%$. Результаты изучения физикохимических и органолептических характеристик масла показали, что масло из плодов $T$. caucasica светло-желтого цвета, с приятным вкусом и имеет следующие показатели: свободные жирные кислоты составляют 1.99 ммол/кг, перекисное число-3.02, йодное число-128.4, весовая доля фосфор содержащих веществ-91ммол/кг. Изучение метиловых эфиров жирных кислот масла методом газо-жидкостной хроматографии выявило наличие в его составе 13 жирных кислот: миристиновая, пальмитиновая, пальмитолеиновая, маргариновая, гептадеценовая, стеариновая, мальвалиновая, олеиновая, элаидиновая, линолевая, линолеиновая, гандоиновая, стеркуловая. Среди полинасыщенных жирных кислот преобладает линоленовая (46.06\%), среди мононенасыщенных кислот - олеиновая (16.92\%), среди насыщенных кислот-пальмитиновая (9.36\%), а из циклопропеноидных жирных кислот первое место занимает стеркуловая кислота (13.35\%). Физико-химические и органолептические показатели, состав и содержание биологически ценных жирных кислот масла плодов T. caucasica позволяют рекомендовать его для использования в пищевых, лекарственных и косметических целях.

Ключевые слова: плод, масло, хроматография 